a sulphur-crested cockatoo (Cacatzua galerita) from Australia. Soon after my arrival in England $I$ had occasion to cut his wing, and this destroyed all his former friendly feelings towards me. On my removal from Blackheath to Dublin, I placed him for a few weeks in the Zoological Society's Gardens, Regent's Park. Being in London in May I brought him with me on my return to this city. I went to the Gardens for him myself, and was interested and somewhat pleased to find, on speaking to him, that he had apparently forgotten me. On my way, in a cab, to the hotel where I was staying, he was very friendly; but on my arrival there, as soon as I took off my hat, it was evident that he recognised me, for his old manner at once returned. On arrival here he appeared to remember my children, and resumed his forme friendliness towards them, but he still regards me as his enemy.

I 7 , Leinster Square, Rathmines, Dublin S. J. WhitmeE

\section{Proceedings of the Aberdeenshire Agricultural} Association, 1878

YOUR article (vol, xx. p. 288) touches a subject of vital importance to the farmer in these bad times, and I hope you will follow it up by an appeal to $\mathrm{Mr}$. Lawes and to the Royal Agricultural Society of England to institute a parallel and independent course of experiments, in order to test the conclusion in regard to phosphatic manures announced by the Scotch Association

The possible presence of humic, carbonic, and other acids in more than usual proportion in Aberdeenshire soil and water has ff ten occurred to me as accounting for the similarity of results between those local experiments of soluble and insoluble phos phates, but it can hardly be denied that a case has been established for further experiments. The fact that acid and mantre makers have a direct pecuniary interest in the existence of a prejudice in favour of soluble phosphate might alone have led crors to require some evidence before spending their money under such scientific dictation, but now that they have three years' experiments testifying distinctly against the doctrine, they nay surely look to their advisers for something more than bare assertions on authority that a "mineral phosphate is of little or no value as a maure until it has been rendered soluble by acid in course of manufacture."

Wrexham, July 27

\section{Spicula in Helix}

Whilst dissecting, a few days ago, a common garden snail (Heivix aspersa), I came across two calcareous spicula, lying immediately under the "albuminiparous gland," which I cannot find mentioned in any of the text-books. I at once dissected three the: snails of the same species, and in two $I$ found no spicula, while in the third I found one lying in the same place as the two before-mentioned. Can any reader of NATURE tell me whether these are of the same nature as the diffused spicula of Doris, or if not, of what nature they are? They could not have been "spicula amoris" (Huxley) of the dart-sac, as they were not contained in any sac at all, but were lying free in the above position.

3, Waterfield Terrace, Blackheath, S.E. EDVD. B. PARFITI

GENERAL RESULTS OF EXPERIMENTS ON

FRICTION AT HIGH VELOCITIES MADE IN

ORDER TO ASCERTAIN THE EFFECT. OF BRAKES ON RAILWAY TRAINS 1

II.

CGME special experiments were made with blocks of $\checkmark$ small area. The brake-blocks generally used in these experiments were 12 inches long, by 3 inches wide, giving a surface of 36 square inches; the small brake-blocks were made so as to afford a surface of pressure against the wheel of only one-third of this amount, or I2 square inches, thus making the pressure per square inch three times as great as before. The diminution of surface was obtained by casting projections upon the face of the block. The author is not prepared to say that any greater coefficient of friction was obtained by the extra pressure per square inch, although in one of the experiments, at a velocity of sixty miles an hour, the rotation of the wheels was arrested by these blocks, whilst this effect had not been produced at that speed in other experiments. The experiments on this form of block were stopped because the blocks were entirely worn down in the course of about twelve experiments.

Mr. Rennie showed ${ }^{x}$ that high pressures per square inch produced a greater coefficient of friction between surfaces either moving very slowly or nearly at rest; but it must be borne in mind that the author's experiments were made with high velocities, whereby a serious element of disturbance is introduced, viz., the grinding away of the surface ; and it is therefore probable that the increase in the coefficient of friction due to increased pressure, may have been neutralised by the lubricating effect of the fine particles ground off the surfaces.

While no certain opinion can be expressed as to the relation which the coefficient of friction bears to pressure, so far as these experiments are concerned, it is quite clear that in proportion as the pressure is increased or diminished so will the actual friction obtained be increased or diminished. When the friction which exists between the brake-blocks and the wheel reaches a certain point, the wheel ceases to rotate, and becomes fixed. This point is reached when the frictional resistance of the blocks exceeds the adhesion between the wheel and the rail if the speed is kept up ; or, if the speed is slackening, when it exceeds the adhesion between the wheel and the rail, plus the effort required to retard the rotation of the wheel equally with the retardation of the train; and the excess of resistance then acts as an unbalanced force, tending to destroy the momentum of the wheel.

Usually there are in a train a certain number of vehicles braked and a certain number unbraked. If the brakes acted on all the wheels, then the rotating momentum of the wheels does not add to the distance in stopping a train, because that momentum can be acted upon by the brakes directly, without in any way affecting the adhesion of the wheels to the rails. It simply requires an additional amount of brake-block pressure.

With the unbraked portion of a train the rotating momentum of the wheels is an addition to the momentum due to the weight of the train (including therein the actual weight of the wheels), which cannot be utilised for retardation; and it therefore seems important that there should be brakes on every wheel of a train.

As it thus appears that it is the adhesion which governs the retardation which the brake-blocks can exert $u_{f}$ on wheels, it is manifest that the pressure brought to act on the brake-blocks should never give an amount of friction which exceeds the adhesion. At a high speed, however, the pressure required to produce a degree of friction equal to the adhesion is much greater than what is required at a low speed.

The following table gives approximately the proportion which the pressure to be applied to the bralke-blocks should bear to the weight upon the braked wheels, with coefficients of adhesion between wheel and rail varying from ' 30 to 15 of the weight on the wheels :-

Ratio of Brake-Block Pressure to Weight on Wheels

\begin{tabular}{|c|c|c|c|c|c|}
\hline \multicolumn{2}{|c|}{ Speed. } & \multicolumn{4}{|c|}{$\begin{array}{l}\text { Approximate ratio of total pressure on brake- } \\
\text { blocks to total weight on braked wheels. }\end{array}$} \\
\hline $\begin{array}{l}\text { Feet per } \\
\text { second. }\end{array}$ & $\begin{array}{l}\text { Miles per } \\
\text { hour. }\end{array}$ & $\begin{array}{c}\text { Coefficient } \\
\text { of adhesion } \\
0^{\circ} 30 \text {. }\end{array}$ & $\begin{array}{c}\text { Coefficient } \\
\text { of adhesion } \\
0^{\circ} 25 .\end{array}$ & $\mid \begin{array}{c}\text { Coefficient } \\
\text { of adhesion } \\
0^{\circ} 20 .\end{array}$ & $\begin{array}{l}\text { Coefficient } \\
\text { of adhesion } \\
0^{\circ} 15 .\end{array}$ \\
\hline $\begin{array}{l}\text { I I } \\
22 \\
29 \\
44 \\
59 \\
73 \\
88\end{array}$ & $\begin{array}{l}7 \frac{1}{2} \\
15 \\
20 \\
30 \\
40 \\
50 \\
60\end{array}$ & $\begin{array}{l}\mathrm{I} \cdot 20 \\
\mathrm{r} \cdot 4 \mathrm{I} \\
\mathrm{r} \cdot 64 \\
\mathrm{r} .83 \\
2.07 \\
2.48 \\
4.14\end{array}$ & $\begin{array}{l}\text { I.04 } \\
\mathrm{I} \cdot 18 \\
\mathrm{I} \cdot 37 \\
\mathrm{r} \cdot 53 \\
\mathrm{r} \cdot 73 \\
2.07 \\
3^{\circ} 47\end{array}$ & $\begin{array}{l}0.83 \\
0.94 \\
1.09 \\
1.22 \\
1.38 \\
1.65 \\
2.77\end{array}$ & $\begin{array}{l}0.60 \\
0.70 \\
0.82 \\
0.92 \\
1.04 \\
1 \cdot 24 \\
2.08\end{array}$ \\
\hline
\end{tabular}

I Phil. Trans. for 1829 , p. 159 
It will be seen that, when the adhesion equals 30 of the weight, a pressure equal to $I^{\prime} 2$ of the weight would skid the wheel at $7 \frac{1}{2}$ miles per hour, whilst a pressure equal to $4^{\circ} \mathrm{I} 4$ times the weight would be required to do so at 60 miles per hour.

On the other hand, if the adhesion is only i 5 , the pressure requisite to skid the wheel would be only 60 of the weight at $7 \frac{1}{2}$ miles per hour, and 2.08 of the weight at 60 miles per hour.

Thus the efficiency of a brake depends upon the pressure being proportioned to the speed and to the adhesion. If the adhesion were always uniform, the rule would be very simple; but this is not the case.

The adhesion of the wheels to the rails varied according to the materials, that is, whether the train was travelling upon iron or steel rails; and according to the state of the rail, whether dry, wet, or sanded.

On dry rails it was found that the coefficient of adhesion of the wheels was generally over '20. In some cases it rose to 25 , or even higher. On wet or greasy rails, without sand, it fell as low as 15 in one experiment, but averaged about 'I8. With the use of sand on wet rails it was above 20 at all times; and when the sand was applied at the moment of starting, so that the wind of the rotating wheels did not blow it away, it rose up to 35 , and even above 4o. Consequently, the retarding effect of the brakes would be greatly increased, were means devised for placing sand under every wheel to which a brake is applied, during the progress of a stop.

The effect in stopping a train is greatest when the friction between the brake-blocks and the wheels amounts to a quantity just short of the resistance caused by the adhesion, because as soon as the brake-block friction exceeds the adhesion, the wheel becomes fixed and begins to slide. In order, however, to secure the best results in stopping, it is obviously necessary that the brake-block pressure should be regulated to give a friction about equal to the adhesion of the wheels at every stage during the progress of a stop.

There is no reason why, in the progress of mechanical science, these conditions should not be regulated by a self-acting arrangement.

Mr. Westinghouse has devised a valve to regulate the pressure between the blocks and the wheels. The principle of the valve is, in the first place, to prevent the actual friction from exceeding the adhesion at any point; and in the next place, whilst allowing the fullest amount of pressure necessary to produce the maximum friction to be applied to the brake blocks when the brakes are first put on, that is to say, when the speed is high at the commencement of a stop, to reduce that pressure gradually during the progress of the stop, so as to maintain as nearly as possible a uniform amount of friction.

As the adhesion varies it is necessary to consider what amount of adhesion for purposes of retardation can be safely calculated upon.

The following table shows the distances required to stop a train on a level line from a speed of fifty miles per hour, with a retarding force of from 5 to 30 per cent. of the total weight of the train :-

\begin{tabular}{|c|c|c|c|}
\hline $\begin{array}{l}\text { Percentage of } \\
\text { retardation. }\end{array}$ & $\begin{array}{l}\text { Yards run at fifty } \\
\text { miles per hour. }\end{array}$ & $\begin{array}{l}\text { Percentage of } \\
\text { retardation. }\end{array}$ & $\begin{array}{l}\text { Yards run at fifty } \\
\text { miles per hour. }\end{array}$ \\
\hline 5 & $555^{\frac{2}{3}}$ & I8 & I $54 \frac{1}{3}$ \\
\hline 10 & $277^{\frac{2}{3}}$ & 20 & 139 \\
\hline 12 & $231 \frac{1}{3}$ & 25 & III \\
\hline 15 & 185 & 30 & $92 \frac{2}{3}$ \\
\hline
\end{tabular}

If the brakes act upon each wheel, then a retardation of ro per cent. of the load carried by each wheel-counting the rotating momentum as part of the weight-will stop a train in $277 \frac{2}{3}$ yards.

If the brakes act upon only half of the weight of a train a retardation of 20 per cent. would have to be exerted upon the braked balf to produce the same result. As pointed out, 20 per cent. adhesion is rather above the average obtainable, while 25 per cent. is the highest result obtained under the most favourable circumstances at any considerable speed, or except when sand was applied to wheels moving slowly.

The above table should be carefully noted, for it will be seen that, even if brakes act upon all wheels, 25 per per cent. retardation will only give twenty-eight yards better result than 20 per cent., or if half of the train only be braked, it will give fifty-nine yards advantage.

A consideration of this feature of the brake problem points out ( $I$ ) that the advantage to be gained by trying to obtain above 20 per cent. retardation on each wheel is greatly overbalanced by the risk of "skidding ;" and (2) that it is far easier and safer to make a stop in 250 yards from fifty miles per hour with the whole train braked, than with brakes upon only half of the train.

The following are some of the results of the earlier experiments, obtained with Mr. Westinghouse's pressureregulator :-

\begin{tabular}{|c|c|c|c|c|c|c|c|c|c|c|c|c|c|c|}
\hline \multirow{2}{*}{$\begin{array}{l}\text { No of } \\
\text { experi- } \\
\text { ment. }\end{array}$} & \multirow{2}{*}{ Gradient. } & \multirow{2}{*}{$\begin{array}{l}\text { Speed. } \\
\text { Miles per } \\
\text { hour. }\end{array}$} & \multicolumn{3}{|c|}{ Condition of stops. } & \multicolumn{3}{|c|}{$\begin{array}{l}\text { Total brake block pressure, } \\
\text { P, on the four wheels. }\end{array}$} & \multicolumn{2}{|c|}{$\begin{array}{l}\text { Percentage of } \\
\text { brake block pres- } \\
\text { sure to weight on } \\
\text { wheels. }\end{array}$} & \multicolumn{3}{|c|}{$\begin{array}{l}\text { Observed coefficient of fric- } \\
\text { ticn between brake blocks } \\
\text { and wheels on one pair of } \\
\text { wheels. }\end{array}$} & \multirow{2}{*}{$\begin{array}{c}\text { Mean re. } \\
\text { tardation } \\
\text { calcu- } \\
\text { lated } \\
\text { from stop. }\end{array}$} \\
\hline & & & $\begin{array}{l}\text { Time of } \\
\text { stop. } \\
\text { Seconds. }\end{array}$ & $\begin{array}{l}\text { Distance } \\
\text { run in } \\
\text { yards. }\end{array}$ & $\begin{array}{l}\text { Distance } \\
\text { reduced } \\
\text { to fifty } \\
\text { miles per } \\
\text { 'hour. } \\
\text { Yards. }\end{array}$ & $\begin{array}{l}\text { Maxi- } \\
\text { mum. }\end{array}$ & $\begin{array}{l}\text { Middle } \\
\text { of expe- } \\
\text { riment. }\end{array}$ & $\begin{array}{c}\text { End or at } \\
\text { skid. }\end{array}$ & 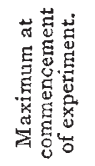 & 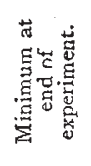 & 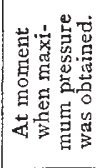 & $\begin{array}{l}\text { At } \\
\text { middle of } \\
\text { experi- } \\
\text { ment. }\end{array}$ & $\begin{array}{l}\text { At end } \\
\text { of expe- } \\
\text { riment. }\end{array}$ & \\
\hline$x$ & $+\frac{3}{264}$ & 60 & $\mathrm{I} 2 \hat{\hat{z}}$ & 171 & IIS & 32370 & 31200 & 23010 & 160 & II 4 & $\cdot 129$ & $\cdot 125$ & $\cdot 24 I$ & $23^{\circ} 3$ \\
\hline 2 & $+3 I Y$ & 60 & $\mathrm{I} 2 \frac{\mathrm{t}}{4}$ & 167 & II 6 & 32760 & 308 ro & 29250 & 162 & 145 & $\cdot 145$ & $\cdot \mathrm{I} 6 \mathrm{I}$ & skid & $23^{\circ} 9$ \\
\hline 3 & $+\frac{1}{33 \sigma}$ & 55 & IO $\frac{1}{2}$ & $\mathrm{I}_{4} \mathrm{I}$ & II 6 & 28470 & 27690 & I6380 & $14 \mathrm{I}$ & 81 & . 160 & $\cdot 776$ & $3 I$ & $23 \cdot 8$ \\
\hline 4 & 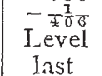 & 57 & $18 \frac{1}{2}$ & 223 & 171 & 24570 & 15990 & 7800 & 122 & 39 & $\cdot{ }_{157}$ & $\cdot 158$ & 35 & $16 \cdot 8$ \\
\hline 5 & $\begin{array}{l}\text { thirty } \\
\text { yards } \\
-\frac{1}{7} 6\end{array}$ & 55 & 18 & 227 & 194 & $\times 755^{\circ}$ & 14430 & 8190 & 87 & 40 & $\cdot 46 \mathrm{r}$ & $\cdot 182$ & $\cdot 309$ & $\times 4: 3$ \\
\hline
\end{tabular}

In the second experiment the pressure was not reduced fourth and fifth experiments the pressure was insufficient with sufficient rapidity to prevent the skidding, and in the at the beginning 'of the experiment. From these and 
other experiments it was found that the best results were obtained in cases where the pressure applied at first was from about $1 \frac{2}{3}$ to twice the weight on the wheels, and where the reduction of the pressure was effected with sufficient rapidity towards the end of the stop to prevent the friction being sufficient to skid the wheels.

The necessity for the instantaneous application of the maximum brake-block pressure throughout the train is evident from the fact that, at a speed which is frequently obtained, namely, 60 miles per hour, a train passes over $\& 8$ feet each second; therefore the loss of two or three seconds in applying the brakes means often the difference between safety and danger, and the rapidity of a stop largely depends upon the rapidity with which all the brake-blocks can be brought to act against the wheels of a train.

This points to the advantage of being able to move the brake-blocks with great rapidity from their position of inaction to that of contact with the wheels; because it is essential to provide that the brake-blocks, when out of use, shall be removed to a distance from the wheels sufficient to prevent the possibility of their dragging against the wheels, and thus retard the progress of the train. The question of the rapidity with which brakes can be applied in practice is thus one of much importance.

Some experiments were made in October, I 878 , upon the North Eastern Railway, on a train fitted with the vacuum brake, and one fitted with the Westinghouse brake to ascertain the time which was required after moving the brake-handle to set the brakes with various degrees of force in different parts of the train. The following table shows the result arrived at :-

\begin{tabular}{|c|c|c|c|c|c|c|c|c|}
\hline \multirow[b]{2}{*}{$\begin{array}{l}\text { Place of expe. } \\
\text { rimental yan } \\
\text { from engine. }\end{array}$} & \multicolumn{4}{|c|}{ Vacuum brake. } & \multicolumn{4}{|c|}{$\begin{array}{c}\text { Westinghcuse automatic } \\
\text { brake. }\end{array}$} \\
\hline & 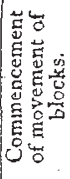 & 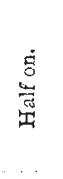 & 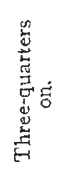 & 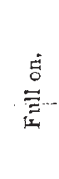 & 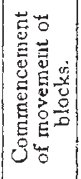 & 离 & 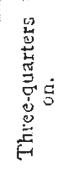 & $\stackrel{\text { हี่ }}{\stackrel{\Xi}{\exists}}$ \\
\hline Ist vehicle & $\frac{\operatorname{secs}}{\frac{1}{2}}$ & $\begin{array}{c}\text { secs. } \\
3\end{array}$ & $\begin{array}{c}\text { secs. } \\
7\end{array}$ & $\begin{array}{l}\text { secs. } \\
\text { II }\end{array}$ & secs. & secs. & $\begin{array}{r}\text { secs. } \\
\frac{3}{4}\end{array}$ & secs. \\
\hline 7the, & 2 & $6 \frac{1}{2}$ & $8 \frac{1}{9}$ & 14 & I & I $\frac{3}{4}$ & 2 & $2 \frac{\bar{x}}{2}$ \\
\hline I $3^{\text {th }}$, & $3 \frac{1}{2}$ & $7 \frac{\frac{1}{2}}{2}$ & $9 \frac{\frac{1}{2}}{2}$ & 14 & $1 \frac{3}{4}$ & $2 \frac{3}{4}$ & $3^{\frac{1}{8}}$ & $3 \frac{1}{2}$ \\
\hline 2 Ist, & $5 \frac{1}{8}$ & 17 & 30 & - & 3 & $4 \frac{1}{2}$ & 5 & $5 \frac{1}{2}$ \\
\hline
\end{tabular}

A long interval of time between brakes coming on at the front and rear of a train may become a source of danger; and improvements have been introduced in both the vacuum and Westinghouse apparatus since that date to reduce the interval as shown by the experiments.

In the Westinghouse brake a simplified triple-valve has been adopted, the friction has been reduced by the use of an enlarged pipe and by the removal of bends in the connections between the carriages; by these alterations the interval of time required to put on the brakes, as shown in the above table, bas since been reduced by nearly onehaif, and an experiment recently made on the application of the brake in rear of a train of twenty-four vehicles on the Western Railway of France showed that the pressure commenced to be brought on in one second, and was fully on in two and a half seconds from the time of first moving the brake lever.

The importance of simultaneous action of the brakes in every part of a train arises from the fact that the train is not a rigid mass, but is made up of separate vehicles conrected by means of spring draw-bars and buffers. The length of the train can thus be modified to a certain extent by the degree of compression of these springs. In a recent experiment on the North-Eastern Railway the train con- sisted of twenty-four carriages, and the whole extent to which the buffers could be compressed amounted to 35 feet. A train travelling at 60 miles an hour moves at 88 feet in a second. If the brakes act on the front part of the train before they affect the hind part the speed of the front carriages may be diminished by 10 to 18 feet in a second, whilst the hind part moves on with undiminished speed; thus the hind part may press against the front part with a force of from 12 to 20 foot tons for every ton weight of the hind vehicles. The buffer springs would be compressed by this force and remain so till the brakes acted equally on all the wheels, when a reaction of the buffer springs would take place; this reaction creates the violent jerks often felt with continuous brakes, and occasionally results in fractures of couplings and draw-bars. In a perfect brake the application would be instantaneous; and simultaneous on all the wheels of a train.

It is beyond the scope of this paper to enter fully into the merits of different kinds of brakes, but it may be convenient to sum up what seem to be the requirements of a perfect brake.

I. It should be fitted to act upon each wheel of the engine, tender, and every other vehicle in a train of ariy length. The brake-blocks, when out of action, must be kept a certain distance away from the wheels, in order to prevent any liability to drag against the wheels; and this distance, after being once adjusted, gradually increases by the wear of the blocks, and often exceeds three-quartei's of an inch; while the springing of the brake-gear under great strain also adds to the extent of movement required. in the brake force before the blocks are fully applied. Hence the brake gear should be so adjusted as to be capable of moving the brake blocks instantaneously through a space of one inch.

2. However brought into action, it should be capable of exerting upon the blocks of each pair of wheels, within two seconds, a force of twice, or at the very least oneand-three-quarter times, the load on those wheels.

3. The brake-block pressure acting on each whesl should be regulated so that the friction between the brake-biock and the wheel may always be limited so as not to exceed the adhesion between the wheel and the rail; by which means it will produce the maximum effect at each moment of its application.

4. The brake-block pressure should be capable of beirgg applied by engine-driver or by guards.

5. The engine, tender, and vehicles should each carry its own store of brake-power, which should be independent of the brake-power on any other vehicle.

6. The brake-block pressure should be automatically applied to every vehicle by the separation of the train into two or more parts, and it should also be applied by the act of the wheels of any carriage leaving the rails.

7. The brake-block pressure should be automatically applied by such failure of the connections or appliances as would render it afterwards incapable of application until the failure had been remedied.

8 . The brake-block pressure should be capable of application with any degree of force up to the maximum, and it should be capable of continued action on inclines, or, of repeated applications at short intervals at junctions and stations.

In addition to these requirements, the questions of cost, durability, convenience in operation, and other essential points, will of course come under consideration.

The experiments which have been here described were made on trains travelling under conditions which were necessarily continually varying, both in respect of the condition of the rails and other matters; and they therefore contained many elements beyond the reach of calculation. It is hoped that some opportunity may arise, ere long, for resuming experiments on friction at high velocities under conditions whence these elements of disturbance nay be eliminated. Meanwhile it is evident 
that a continuous brake, capable of being applied sinultaneously to every wheel of a train under the conditions which have been enumerated in this memorandum, is a much more practical and scientific method of bringing a train to rest than the old plan of concentrating the brakepower in two or three heavy brake vans placed in different parts of the train, and leaving the rest of the wheels without brakes.

The advantage which thus evidently ensues from utilising the adhesion of every wheel of a train for the purpose of stopping a train suggests the further consideration as to whether it would not be a more scientific arrangement, as well as more economical in regard to the permanent way of railways, to utilise the adhesion of every wheel of a train for causing the train to move forward, instead of depending for the moving force upon the adhesion of one heavy vehicle alone, viz., the locomotive. Experiments connected with the action of brakes on railway trains require very delicate apparatus; the credit of the design of the apparatus used in these experiments belongs to $\mathrm{Mr}$. Westinghouse. The efficiency of the arrangements for making the experiments is due to the London, Brighton, and South Coast Railway Company, as represented by Mr. Knight, their general manager, who afforded every facility for the use of the line, and by Mr. Stroudley, the locomotive engineer of the Company.

DOUGLAS GALTON

\section{OUR ASTRONOMICAL COLUMN}

THE COMET OF 1532. - This comet, the second of the ive observed by Apian, as described in his rare work, the "Astronomicum Cæsarium," has been the subject of much computation and discussion in connection with its long-assumed identity with the comet of $166 \mathrm{I}$ observed by Hevelius, to which attention was directed by Halley when he published his "Synopsis of Cometary Astronomy." We read: "Halley was apt to believe that the comet of 1532 was the same with that observed by Hevelius in the beginning of $166 \mathrm{r}$, but Apian's observasions, which are the only ones we have, are too inaccurate to determine anything certain from them in so nice an affair." Pingré fully believed in the identity of the comets of 1532 and $166 \mathrm{I}$, and in his "Cometographie" has endeavoured to point out several previous appearances of the same body, as in the year 1402, when he expresses his conviction that the great comet recorded in so many of the European chronicles about Easter was no other than the one in question. Between the perihelion passages of 1532 and $165 \mathrm{r}$ is a period of $128 \frac{1}{4}$ years, and so the return of the comet was long expected about 1789 . Shortly before this year, however, the rediscussion of the observations of 1532 and 1661 was made the subject of a prize by the Paris Academy of Sciences, which was gained by Mechain.

His calculations threw much doubt upon the presumed identity of the comets, indeed were pretty generally considered as decisive against it. Olbers also recomputed the orbit from the observations of 1532 , and although he found one much closer to that of the comet of $x 66 \mathrm{r}$ than Mechain had done, seems to have arrived at the conclusion that the comets were not identical. Nevertheless, as the year 1789 approached, sweeping-ephemerides were prepared to facilitate a search, the then AstronomerRoyal, Dr. Maskelyne, taking a part in this work. The search was ineffectual, no one of the comets which appeared about that year presenting any indications of being the expected body.

It is probable that the elements of the comet of 1532 are open to even greater uncertainty than has been usually supposed. Apian's observations are clearly affected with large errors, yet we are under the necessity of relying upon them. as the best data available, neither the vague and contradictory observations (if they deserve the name) by Fracastor at Verona, nor those of Vogelin at Vienna, being of service in the determination of a more certain orbit than can be inferred from the observations in the "Astronomicum Cæsarium." Apian appears to have observed at Dresden, and the times of observation are given by altitudes of Regulus and Arcturus; the amplitudes of the comet (S. to E.) and its altitudes are recorded. The positions of the stars for $1532^{\circ} \circ$ were:-

$$
\begin{aligned}
& \text { Right Ascension. Declination. } \\
& \begin{array}{lllllllllll}
\text { Regulus } & \ldots & \ldots & \ldots & 145 & 49^{\prime} 7 & \ldots & \ldots & +14 & 12 \cdot 1
\end{array} \\
& \begin{array}{llllllllll}
\text { Arcturus } & \ldots & \ldots & \ldots & 208 & 35^{\circ} 2 & \ldots & \ldots & +21 & 40.1
\end{array}
\end{aligned}
$$

Assuming Apian's station to have been in longitude oh. $54 \mathrm{~m}$. $56 \mathrm{~s}$. E. and latitude $51^{\circ} 3^{\prime} 7$, his data fumish the following places, which, except for the first day, do not differ more than might have been expected from Pingrés reductions:-

$$
\begin{aligned}
& \text { G.M.T. Right Ascension. Declination. } \\
& \text { I532, October } 1.6635 \quad \ldots \quad \text { I } 5543.8 \ldots,-426.9 \\
& \begin{array}{llllllll}
2.649 ! & \ldots & 160 & 10.7 & \ldots & -3 & 20^{\prime} 3
\end{array} \\
& \begin{array}{lllllll}
30.6699 & \ldots & 206 & 3.6 & \ldots & +3 & 48.6
\end{array} \\
& \begin{array}{lllllll}
31.6939 & \ldots & 208 & 48.3 & \ldots & +420^{\circ} 6
\end{array} \\
& \text { November } 7.6747 \quad \ldots \quad 2185 y^{\prime} 1 \quad \ldots+555^{\circ} 8
\end{aligned}
$$

We subjoin an orbit depending on the observations of October 2, 30, and November 7, and also Olbers' elements from Hindenburg's Magazin fir Mathenatik, I787 :-

$$
\text { New Orbit. Olbers. }
$$

Perihelion passage ... Nov. $3^{1} 1355$ G.M.T. ... Oct. $28 \cdot 3324$

$\begin{array}{lllllllllll}\text { Long, of perihelion } & \ldots & \ldots & \text { i } 74 & 5 & \text { I } & \ldots & \ldots & \ldots & \text { Iin } & 48\end{array}$

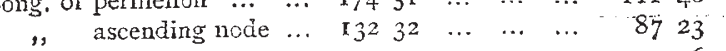
$\begin{array}{llllllllllll}\text { Inclination } & \ldots & \ldots & \ldots & \ldots & 57 & 41 & \ldots & \ldots & \ldots & 3^{2} & 3^{6}\end{array}$ $\begin{array}{llllllll}\text { Perihelion distance } & \ldots & \ldots & 0.6736 & \ldots & \ldots & \ldots & 0.5192\end{array}$ $\begin{array}{llllllllll}\text { Motion ... } & \ldots & \ldots & \ldots & \ldots & \text { Direct. } & \ldots & \ldots & \ldots & \text { Direct. }\end{array}$

The comparison with the above-observed positions is slightly in favour of Olbers' orbit, though this differs from the place for November 7 by $-1^{\circ} 40^{\prime}$ in longitude and $-4^{\circ} 36^{\prime}$ in latitude. Still it will appear that Apian's observations may be represented within their evident limits of error, by orbits which differ widely.

The Chinese observed this comet from September 2 to December 25 , according to the extracts from their annals which have been given by $\mathrm{E}$. Biot and Williams: on the former date, according to Olbers' elements, the comet was in longitude $98^{\circ}$, latitude $47^{\circ}$ south, distant from the earth 0.78 , and on the latter date in longitude $249^{\circ}$, latitude $16^{\circ}$ north, distant 2.13 . The mention of the comet having traversed Cygnus probably applies to that of I533; at any rate the comet of 1532 could not have passed through that constellation.

The Sun's Parallax. - Mr. Dayid Gill, writing from Madeira, on his voyage to the Cape of Good Hope, to take the direction of the Royal Observatory, as successor to $\mathrm{Mr}$. Stone, stales in a communication to the Royal Astronomical Society, that the reduction of the observations of Mars, made during his expedition to Ascension, in 1877 , have been so far completed that he is able to give the resulting solar parallax. He presents values, differing little inter se, deduced from various combinations of the observations and, as the definite figure, $8^{\prime \prime} \cdot 78$, which being interpreted with the aid of Col. Clarke's last determination of the earth's equatorial semi-diameter, implies that the mean distance of the earth from the sun is 93, I0I,000 miles. This is a smaller parallax than perhaps was generally looked for, though not differing materially from several values which have been worked out recently. 